\title{
PERAN MUALIM JAGA DALAM BERNAVIGASI YANG AMAN DI ALUR PELAYARAN SEMPIT PERAIRAN TANAH GROGOT
}

\author{
Muhammad Iqbal Bayu Ismail ${ }^{a}$, Suherman ${ }^{b}$, dan Okvita Wahyunic \\ ${ }^{a}$ Taruna (NIT.50134880.N) Program Studi Nautika PIP Semarang \\ ${ }^{\mathrm{b}}$ Dosen Program Studi Teknika PIP Semarang \\ ${ }^{c}$ Dosen Program Studi KALK PIP Semarang
}

\begin{abstract}
ABSTRAK
Dengan semakin meningkatnya perekonomian dunia maka penggunaan transportasi laut semakin padat, khususnya pada daerah pelayaran sempit, seperti selat dan kanal, ataupun daerah yang terkonsentrasi seperti pelabuhan dan persilangan lintasan lalu lintas pelayaran yang dapat menimbulkan risiko tinggi untuk terjadinya kecelakaan pelayaran.

Pelaksanaan upaya agar dapat bernavigasi yang aman kapal MV. OMS Bromo memperhatikan berbagai faktor yang mempengaruhi kemampuan bernavigasi kapal. pengaruh dari luar dan pengaruh dari dalam kapal itu sendiri sangat berperan penting bagi navigator serta pengalaman yang cukup. Penelitian ini menggunakan metode kualitatif yang membahas tentang peran Mualim jaga dalam bernavigasi yang aman di alur pelayaran sempit perairan Tanah Grogot, Kalimantan Timur dilakukan penulis selama praktek berlayar di MV. OMS Bromo. Hasil penelitian yang diperoleh adalah peran Mualim jaga saat bernavigasi sangatlah penting dan kemampuan Mualim jaga dalam bernavigasi menentukan posisi dengan menggunakan panduan bernavigasi di perairan sempit, parallel index, serta ship routeing sangat diperlukan agar tidak terjadi bahaya tubrukan yang akan merugikan banyak pihak.
\end{abstract}

Kata kunci: alur pelayaran sempit, navigasi aman, mualim jaga

\section{PENDAHULUAN}

\section{Latar Belakang}

MV. OMS Bromo merupakan salah satu armada dari perusahaan Orchard Maritime Services Singapura yang memiliki operator perusahaan di Indonesia bernama Maritim Batu bara Pertama di Paiton, Jawa Timur. MV. OMS Bromo merupakan jenis kapal open deck cargo yang mengangkut batu bara dari Tanah Grogot, Kalimantan Timur dan disuplay ke PLTU Paiton, Probolinggo, Jawa Timur. MV. OMS Bromo setiap bulan membawa batu bara dari Tanah Grogot, Kalimantan Timur sebanyak 4 kali. Hal ini disebabkan semakin tingginya kebutuhan batu bara sebagai bahan baku Pembangkit Listrik Tenaga Uap di daerah Paiton, Probolinggo, Jawa Timur sehingga frekuensi distribusi batu bara dari Tanah Grogot, Kalimantan Timur ke Paiton, Probolinggo, Jawa Timur akan semakin meningkat. Tidak menutup kemungkinan nantinya MV. OMS Bromo akan lebih sering memasuki alur pelayaran sempit Tanah Grogot, Kalimantan Timur untuk memuat batu bara.

Lebih dari $80 \%$ perdagangan di dunia dilakukan melalui jalur laut. Fakta ini berpengaruh pada meningkatnya operasi pelayaran yang dilakukan oleh kapal niaga. Kapal-kapal tersebut dapat beroperasi di berbagai daerah atau area antara lain laut lepas, selat, sungai, dan teluk. Di masingmasing daerah operasi kapal laut tersebut memiliki tingkat risiko bahaya yang berbeda. Di alur pelayaran sempit misalnya, terdapat berbagai macam risiko bahaya yang dapat mengancam keselamatan kapal. Kedalaman perairan akan berpengaruh pada kemampuan olah gerak kapal dalam bernavigasi di daerah tersebut. Hal ini juga dapat menimbulkan efek squat kapal yang dapat terjadi ketika UKC (Under Keel Clearance) kecil. Hal ini sebagai akibat dari 
dangkalnya perairan dan dalamnya sarat kapal. Di alur pelayaran sempit Tanah Grogot, Kalimantan Timur yang memiliki rata-rata kedalaman perairan 7 meter, akan sangat berbahaya pada saat kapal berolah gerak di perairan tersebut tanpa adanya suatu pertimbangan khusus diantaranya mengenai pasang surut. Jadi sebelum bernavigasi di alur pelayaran sempit perairan Tanah Grogot, Kalimantan Timur setiap Mualim harus melakukan perhitungan pasang surut yang benar agar dapat bernavigasi dengan aman dan selamat karena pasang surut dapat berubah-ubah pada waktu tertentu dan berpengaruh pada kedalaman perairan.

Kalimantan merupakan pusat sumber batu bara di Indonesia khususnya daerah Banjarmasin, Tanah Grogot, dan Martapura, ketiga daerah tersebut memiliki pelabuhan Pondong batu bara dengan karakteristik yang berbeda. Di Tanah Grogot, Kalimantan Timur misalnya, kapal harus berlayar selama 4 jam di alur pelayaran sempit dengan kedalaman 7 meter agar dapat bersandar di pelabuhan ponding dengan jarak $30 \mathrm{Nm}$ dari Teluk Adang. Oleh karena itu, kapal niaga dengan sarat maksimal 6 meter dapat keluar masuk alur pelayaran sempit tersebut. Saat MV. OMS Bromo bernavigasi di alur tersebut sering menjumpai banyak kapal jenis tug boat, selft propeller oil barges, Ro-Ro ship, nelayan, dan kapal SPB yang lain. Pada tanggal 08 Februari 2016 MV. OMS Bromo hampir mengalami tubrukan dengan tug boat Tinju di lambung sebelah kanan dengan jarak 4 meter saat posisi melintang pelabuhan Pondong ketika memasuki alur pelayaran Tanah Grogot, Kalimantan Timur. Tindakan Nakhoda yang segera menghindar dengan cara dari bahaya tubrukan dengan tug boat tersebut. Dengan cara pada saat MV. OMS Bromo memasuki perairan sempit dengan situasi berhadapan tug boat Tinju yang berada di sebelah lambung kanan MV. OMS Bromo sehingga Nakhoda segera mengambil tindakan dengan merubah haluan kekiri agar kapal terhindar dari tug boat Tinju yang dapat mengakibatkan risiko tubrukan dengan tongkang tug boat Tinju. Oleh sebab itu, Mualim harus meningkatkan pengamatan keliling, memperhatikan kecepatan angin dan jarak antar kapal lain dalam bernavigasi di alur pelayaran tersebut. Agar hal tersebut untuk menghindari risiko tubrukan.

Dengan latar belakang tersebut maka penulis mengambil judul penelitian "Peran Mualim jaga dalam bernavigasi yang aman di alur pelayaran sempit perairan Tanah Grogot".

Berdasarkan latar belakang di atas maka penulis merumuskan permasalahan bernavigasi dengan cara aman saat memasuki alur sempit perairan Tanah Grogot dan peran Mualim dalam bernavigasi secara aman saat berada di perairan Tanah Grogot.

\section{KAJIAN PUSTAKA}

\section{Navigasi}

Menurut Hadi Supriyono \& Achmad Sulistyo (2014), navigasi adalah cara atau seni membawa kapal dari satu tempat ke tempat lain secara selamat, aman dan hemat (safe, secure and efficient).

Navigasi elektronik berarti menavigasikan kapal dengan memanfaatkan peralatan navigasi yang berbasis elektronik yang terdapat di kapal.

Teknologi maritim telah lama mengalami perkembangan yang cukup signifikan. Pada dasa-warsa terakhir ini, perkembangan teknologi tersebut makin bertambah dengan diperkenalkannya sistem-sistem navigasi dan peralatan yang baru. Sejalan dengan itu, penetapan aturan-aturan baik secara nasional maupun internasional juga tidak dapat dihindarkan demi untuk meningkatkan keselamatan dan keamanan pelayaran serta mengurangi pencemaran laut oleh kapal-kapal.

Konvensi internasional tentang keselamatan di laut SOLAS 1974 telah di amandemen beberapa kali sejak diberlakukannya, termasuk aturan-aturan 
tentang keselamatan navigasi sebagaimana dituangkan pada $\mathrm{Bab} \mathrm{V}$ konvensi tersebut. Dengan diberlakukannya amandemen SOLAS 1974, khususnya Bab V (Safety of Navigation), sesuai dengan ketentuan, kapal-kapal harus dilengkapi dengan peralatan navigasi elektronik yang jumlah dan jenisnya makin bertambah. Konsekuensinya adalah perwira tugas jaga anjungan (Mualim jaga) dan Nakhoda kapal diwajibkan mampu mengoperasikan peralatan-peralatan tersebut dengan baik sebagai alat bantu navigasi kapalnya. Oleh karena itu STCW 1978 yang telah di amandemen pada tahun 2010, mensyaratkan kompetensi minimal yang harus dimiliki oleh Nakhoda dan Mualim untuk mengoperasikan peralatan navigasi yang disyaratkan tersebut.

Dalam mempelajari peralatan dan sistem navigasi elektronika, Nakhoda dan Mualim wajib memiliki dasar pengetahuan dasar-dasar elektronika yang cukup, sehingga akan lebih mudah memahami prinsip kerja dan pengoperasian setiap peralatan navigasi yang menjadi tanggung jawabnya, serta mampu memahami kelebihan-kelebihan dan kekurangan-kekurangannya. Berikut ini adalah alat bantu navigasi yang ada di atas kapal seperti:

$>$ Echosounder adalah suatu alat navigasi elektronik dengan menggunakan sistem gema yang dipasang pada dasar kapal yang berfungsi untuk mengukur kedalaman perairan, mengetahui bentuk dasar suatu perairan dan untuk mendeteksi gerombolan ikan dibagian bawah kapal secara vertikal.

$>$ Sistem navigasi RADAR-ARPA (Automatic Radar Plotting Aids) dan ECDIS (Electronic Chart Display and Information System) adalah merupakan alat bantu navigasi yang cukup modern dan sangat diperlukan dalam setiap kesempatan, baik untuk penentuan posisi kapal dari waktu ke waktu, membantu mencegah tubrukan serta merupakan peralatan canggih yang mampu menyimpan data rekaman pelayaran kapal (ECDIS). Pada buku ini, penulis tidak membahas secara rinci karena RADAR, ARPA dan ECDIS pada sistem sertifikasi pelaut di Indonesia, dilaksanakan dalam bentuk diklat keterampilan.

Sistem navigasi satelit, adalah sistem navigasi yang modern dan menjadi sangat penting artinya bagi para navigator pada saat ini. Bahwa sistem navigasi seperti GPS (Global Positioning System) atau DGPS (Differntial GPS) tidak hanya digunakan untuk penentuan posisi kapal saja, tetapi juga bermanfaat untuk mengetahui jarak dan waktu yang harus ditempuh untuk mencapai pelabuhan tujuan, untuk mengetahui sejauh mana kapal mengikuti atau menyimpang dari garis haluan yang telah ditetapkan, waktu dan jarak titiktitik belok (way-point-wp) kapal dari pelabuhan tolak ke pelabuhan tiba, kecepatan rata-rata kapal, dan sebagainya. Mengingat fungsi GPS ini sangat kompleks, sehingga perlu pembahasan yang cukup rinci.

Peralatan-peralatan navigasi baru lainnya seperti Voyage Data Recorder (VDR), Automatic Identification System (AIS), Long Range Identification and Tracking of ship (LRIT) dan Bridge Navigational Watch and Alaram System (BNWAS), adalah alat-alat navigasi modern yang telah menjadi persyaratan yang harus dibawa oleh kapal-kapal menurut SOLAS 1974. Menurut Peraturan Menteri Perhubungan tentang Pemanduan Nomor: PM 57 Tahun 2015 pasal 1 yang berbunyi:

1. Pemanduan adalah kegiatan pandu dalam membantu, memberikan saran dan informasi kepada Nakhoda tentang keadaan perairan setempat yang penting agar navigasi pelayaran dapat dilaksanakan dengan selamat, 
tertib dan lancar demi keselamatan lingkungan.

2. Perairan wajib pandu adalah suatu wilayah perairan yang karena kondisi perairannya wajib dilakukan pemanduan bagi kapal berukuran tonase tertentu.

3. Perairan pandu luar biasa adalah suatu wilayah perairan yang karena kondisi perairannya tidak wajib dilakukan pemanduan, namun apabila Nakhoda atau pemimpin kapal memerlukan pemanduan dapat mengajukan permintaan untuk menggunakan fasilitas pandu.

\section{Olah Gerak}

a. Definisi Olah Gerak

Menurut Subandrijo (2011:1), olah gerak adalah merupakan suatu hal yang penting untuk memahami beberapa gaya yang mempengaruhi kapal dalam gerakannya, sehingga untuk mengolah gerak kapal dengan baik, harus terlebih dahulu mengetahui sifat sebuah kapal, dan bagaimana gerakannya pada waktu berolah gerak.

Olah gerak kapal juga bisa disebut suatu seni karena dalam olah gerak kapal harus memperhatikan berbagai faktor yang mempengaruhi kemampuan daripada olah gerak kapal itu sendiri, baik faktor dari luar maupun faktor dari dalam kapal tersebut. Teori tentang olah gerak kapal sangat penting terutama bila ditunjang oleh praktek pengalaman selama di kapal.

Dapat diartikan bahwa kemampuan olah gerak selain tergantung pada pengaruh dari luar dan pengaruh dari dalam kapal itu sendiri sangat berperan penting bagi navigator kapal serta pengalaman yang cukup di dunia olah gerak kapal.

b. Pemanfaatan Bahan Bakar

1) Penggunaan bahan bakar dibagi menjadi dua yaitu: untuk main engine (mesin induk, ketel induk) dan Auxaliary engine (motor bantu, ketel bantu dan lain-lain). Mesin induk menggunakan fuel oil (minyak berat) selama pelayaran di laut dan menggunakan diesel oil (minyak ringan) selama melakukan olah gerak saat akan masuk atau akan keluar dari pelabuhan.

2) Kecepatan ekonomis, pemakaian bahan bakar ekonomis serta besarnya tenaga pendorong yang dihasilkan dengan besar dan kemampuan mesinnya.

3) Tindakan-tindakan jika terjadi kekurangan bahan bakar saat pelayaran, apabila terjadi kekurangan bahan bakar harus diambil suatu tindakan misalnya pengurangan kecepatan, karena bahan bakar sebanding dengan pangkat dua kecepatannya, pengurangan kecepatan dengan $10 \%$ dapat memberikan pengurangan dalam pemakaian bahan bakar sebanyak 19\% setiap mil lautnya.

\section{Faktor-Faktor yang Mempengaruhi Olah Gerak Kapal}

a. Faktor dari luar

Faktor dari luar disini dimaksud sebagai faktor yang datangnya dari luar kapal, mencakup dua hal penting yaitu keadaan laut dan keadaan perairan. Hal tersebut perlu dipahami karena mengingat keterbatasan kemampuan olah gerak kapal dalam menghadapi cuaca maupun keadaan laut yang berbeda-beda serta gerakan kapal di air juga memerlukan ruang gerak yang cukup besar.

Keadaan laut dapat dipengaruhi oleh beberapa hal, diantaranya:

1) Pengaruh angin

Angin sangat mempengaruhi pada olah gerak kapal terutama pada tempat-tempat yang sempit dan sulit dalam keadaan kapal kosong, walaupun pada situasi 
tertentu angin juga dapat digunakan untuk mempercepat proses olah gerak kapal.

\section{2) Pengaruh laut}

Pengaruh dari laut dibedakan menjadi tiga, yaitu jika kapal didapati ombak dari depan, belakang, dan samping.

a) Ombak dari depan

Karena stabilitas memanjang kapal, menghasilkan GML (tinggi metacenter membujur) yang cukup besar, maka dalam waktu mengangguk, umumnya kapal cenderung mengangguk lebih cepat dari pada periode olengan. Bila ombak dari depan kapal mempunyai kecepatan konstan maka $\mathrm{T}$ kapal $>\mathrm{T}$ ombak.

b) Ombak dari belakang Kapal menjadi sulit dikendalikan, haluan merewang bagi kapal yang dilengkapi dengan kemudi otomatis, penyimpangan yang besar dapat merusak sistemnya, dan kemudi terancam rusak oleh hempasan ombak.

c) Ombak dari samping

Kapal akan mengoleng, pada kemiringan yang besar dapat membahayakan stabilitas kapal. Olengan ini makin besar jika terjadi sinkronisasi antara periode oleng kapal dan periode gelombang semu, kemungkinan terbalik dan tenggelam.

3) Pengaruh arus

Di perairan bebas pada umumnya arus akan menghanyutkan kapal, sedangkan di perairan sempit atau di tempattempat tertentu arus dapat memutar kapal. Pengaruh arus terhadap olah gerak kapal sama halnya dengan pengaruh angin.
Terdapat beberapa hal yang perlu diperhatikan pada faktorfaktor dari luar yang mempengaruhi olah gerak, yaitu:

a) Penyebab timbulnya pengaruh di perairan dangkal Saat kapal bergerak ditengahtengah air, badan kapal akan berpindah dengan mendorong air disekitarnya. Air yang terdorong akan berputar ke arah belakang mengikuti badan kapal. Di tempat yang kedalaman airnya cukup dalam, air yang terdorong akan mengalir ke samping kapal atau pun ke bawah dasar kapal, tetapi apabila kedalaman airnya dangkal maka aliran ke dasar kapal akan terhalangi, sehingga air menjadi susah mengalir dan kebanyakan akan mengitari ke samping kapal. Tersendatnya aliran air seperti ini di sekitar badan kapal yang terjadi pada wilayah air yang dangkal, akan membawa peningkatan massa tambahan dan momen yang terpadu dan mengakibatkan terjadinya putaran tambahan, dan peningkatan hambatan badan kapal serta momen hambatan perputaran. Kemudian, dengan berputarnya aliran air yang ke dasar kapal menjadi ke samping kapal, aliran air yang mengikuti samping kapal menjadi terakselerasi, sehingga timbul perubahan distribusi tekanan di sekitar badan kapal.

Fenomena hidrodinamika di area air yang kedalamannya terbatas tersebut, disebut dengan Swallow Water Effect (dampak air dangkal), tetapi pada aspek pengemudian kapal akan terlihat perubahan 
sebagai berikut:

- Penurunan kecepatan kapal;

- Dalam kemampuan pengemudian, kapal akan menjadi sukar untuk mengubah arah;

- Badan kapal terbenam;

- Perubahan trim.

b) Pengaruh terhadap pengemudian kapal

Bila kedalaman air adalah dangkal, seperti yang dijelaskan sebelumya maka momen inersia putar tambahan dan momen hambatan putar akar meningkat, kemudian mengenai gaya kemudi pun akan membesar meskipun hanya sedikit karena peningkatan slip yang menyebabkan penurunan kecepatan kapal akan memperkuat aliran di belakang baling-baling.

c) Benaman badan kapal dan perubahan trim

Bila melakukan pelayaran di perairan dangkal, karena celah antara dasar kapal dan dasar laut menjadi kecil, maka aliran air yang selama ini mengalir masuk ke bawah dasar kapal akan mengalir ke samping kapal. Dengan aliran air yang mengaliri sekitar badan kapal menjadi aliran dua dimensi, aliran air yang mengikuti samping kapal terakselerasi dan tekanan bagian tengah badan kapaldan turun. Pada akhirnya, karena badan kapal mengambil posisi badan yang baru agar badan kapal seimbang terhadap distribusi tekanan disekitarnya di mana bagian leher haluan dan buritan kapal bertekanan tinggi dan bagian tengah badan kapal bertekanan lebih rendah, maka hasilnya adalah bersamaan badan kapal tenggelam turun dan trim mengalami perubahan.

Trim adalah perbedaan antara draft depan dan draft buritan, trim merupakan sudut kemiringan kapal secara membujur.

Secara umum ketika kapal berada di area perairan dangkal draft depan merupakan trim depan kapal dan apabila kecepatan kapal semakin cepat, akan berubah menjadi trim buritan kapal dan ketika kedalaman air semakin dangkal sehingga trim berubah dari trim depan kapal menjadi trim buritan kapal. Meskipun demikian, pada area perairan dangkal kecepatan normal pada kapal niaga pada bagian depan badan kapal turun sehingga berubah menjadi depan kapal.

d) Perubahan posisi poros putar di perairan dangkal

Karakteristik pemgaruh air dangkal terhadap perubahan posisi pusat putaran adalah apabila airnya dalam maka posisi pusat putaran ketika sudah tenang adalah di sekitar 0,3L ke arah depan pusat berat. Sebaliknya bila air semakin dangkal, posisinya lebih dekat lagi ke pusat berat dan 1,5L arah depan pusat berat. Bila memotong (menyeberangi) kedalaman air $\mathrm{h} / \mathrm{d}=1,1$ maka posisi pusat putarannya memposisikan sedikit di arah belakang pusat berat.

e) Kedalaman perairan yang dapat dengan leluasa 
melakukan pengemudian di dalam pelabuhan

Jarak bebas dan bawah dasar kapal sampai dasar laut disebut dengan kedalaman air bebas (Under Keel Clearance). Di dalam pelabuhan, karena kedalaman airnya relatif dangkal perlu perhatian khusus untuk menjamin clearance antara dasar kapal dengan dasar laut. Saat mengemudikan kapal di dalam pelabuhan, poin yang harus dipertimbangkan untuk menentukan kedalaman air bebas yang diperlukan adalah sebagai berikut:

- Besar perubahan trim dan besar penurunan badan kapal yang terjadi selama kapal melaju, apabila laju kapal dengan kecepatan tinggi di perairan dangkal maka akan terjadi penurunan badan kapal menjadi lebih besar, dan biasanya besar perubahan terjadi pada trim depan kapal.

- Besar penurunan badan kapal oleh perbedaan berat jenis air laut dan mengalir masuknya air sungai dan lainnya. Bila berat jenis air laut di perairan sekitar menjadi lebih kecil, maka badan kapal akan mengalami penurunan.

- Besar penurunan badan kapal yang mengikuti goncangan badan kapal. Bila terjadi heaving (goncangan naik turun), pitching (goncangan vertikal) dan rolling (goncangan horizontal) karena menerima dampak ombak, maka sebagian dasar kapal akan merapat ke dasar laut.

- Dimensi jangkar yang diturunkan, mempertimbangkan ketebalan anchor head atau pada jangkar model JIS adalah tripping palm, agar dasar kapal tidak bersinggungan dengan jangkar, ketika dasar kapal lewat di atas jangkar. Sebaliknya bila air semakin dangkal, posisinya lebih dekat lagi ke pusat berat dari $1,5 \mathrm{~L}$ arah depan pusat berat. Bila memotong (menyeberangi)

kedalaman air $\mathrm{h} / \mathrm{d}=1,1$ maka posisi pusat putarannya memposisikan sedikit di arah belakang pusat berat

b. Faktor dari dalam

1) Baling-baling (propeller)

Mesin penggerak utama (mesin induk) bekerja menggerakkan balingbaling, dengan perantara poros balingbaling sehingga dapat berputar. Prinsip kerja baling-baling ini seperti gerakan sekrup pada ulirnya, dengan permukaan sedemikian rupa dalam bentuk sudut yang kedudukanya beraturan. Pada kapal-kapal modern bahkan kedudukan ini dapat diubahubah dalam kisaran baling-baling berubah pula. Sebagai akibat dari berputarannya baling-baling, maka daun kemudi akan memukul air dan kapal akan bergerak maju atau mundur. Kisar baling-baling adalah jarak yang ditempuh oleh kapal bila baling-baling berputar satu kali $\left(360^{\circ}\right.$ ).

MV. OMS Bromo menggunakan baling-baling ganda. Pada kapal dengan baling-baling ganda merupakan baling-baling ganda putar luar (out turning propeller) maksudnya adalah jika mesin maju 
maka baling-baling kanan akan berputar ke arah kanan dan balingbaling kiri akan berputar ke kiri.

2) Daun kemudi

Disamping baling-baling, kemudi juga salah satu alat yang sama pentingnya dengan baling-baling dalam olah gerak kapal. Hubungan antara daun kemudi dan baling-baling adalah kerja dari baling-baling menghasilkan tekanan air dan menghantam daun kemudi yang disimpangkan, sehingga kapal dapat berbelok kearah daun kemudi yang disimpangkan.

Sementara itu, keadaan perairan dapat dipengaruhi oleh adanya pengaruh perairan dangkal dan sempit, pengertian dangkal dan sempit disini sangat relatif sifatnya, tergantung dari dalam dan lebarnya perairan terhadap sarat dan lebar kapal itu sendiri. Pada perairan sempit, jika lunas kapal terlalu dekat dengan dasar perairan maka akan terjadi ombak haluan atau buritan disisi kiri atau kanan kapal serta arus bolak-balik. Hal ini disebabkan karena pada waktu balingbaling bawah bergerak ke atas terjadi pengisapan air yang membuat lunas kapal menyentuh dasar perairan, terutama jika berlayar dengan kecepatan tinggi maka kapal akan terasa menyentak-nyentak dan dapat mengakibatkan kemungkinan menyentuh dasar. Gejala penurunan tekanan antara dasar laut dengan lunas kapal berbanding terbalik dengan kuadrat kecepatannya.

Terdapat beberapa pengaruh olah gerak dari dalam yang bersifat tetap yaitu:

1) Bentuk kapal

Perbandingan antara panjang dan lebar kapal, mempunyai pengaruh yang cukup besar terhadap gerakan kapal pada waktu merubah haluan. Kapal yang pendek akan lebih mudah untuk membelok dari pada kapal yang panjang.

2) Macam dan kekuatan mesin

a) Mesin uap torak

Jenis ini mempunyai beberapa keuntungan dan kerugian. Keuntungannya gerakan, maju dan mundurnya cepat, dengan pengaruh kopling. Tenaga yang dihasilkan besar jika dibandingkan dengan motor. Kekuatan mundur $80 \%$ kekuatan majunya, dan apabila terdapat kerusakan salah satu silinder mati kapal masih dapat berolah gerak. Kerugiannya, waktu persiapan yang terlalu lama dan tidak ekonomis karena memakan ruangan yang besar.

b) Mesin diesel

Persiapannya lebih cepat dan kekuatan mundurnya 70\%-80\% dari kekuatan maju. Untuk menghidupkan mesinnya cepat tetapi kadang-kadang kurang dapat dipercaya hasilnya antara teori dan realita. Untuk menghidupkan diperlukan angin dari kompresor yang persediaannya terbatas, yang akan sangat menyulitkan pelaksanaan olah gerak, terutama pada waktu olah gerak ditempat yang sulit.

c) Mesin turbin

Mempergunakan turbin maju dan turbin mundur tersendiri secara terpisah, kekuatan mundur lebih kecil dari pada kekuatan majunya.

4) Berolah gerak di sungai

Subandrijo

(2011:137), mengemukakan bahwa apabila berlayar di sungai, maka yang perlu diketahui ialah:

a. Alur sebelah mana yang terdalam;

b. Di mana terdapat ambang 
atau tempat yang dangkal;

c. Di sisi atau sebelah manakah terdapat arus yang paling kuat;

d. Di sisi mana yang arusnya paling lemah.

Pada alur pelayaran sempit terutama apabila alur pelayaran sempit tersebut lurus dan sempit. Dalamnya air berpengaruh terhadap kekuatan arus, maka pada daerah yang dalam terdapat arus yang kuat.

\section{5) Pengertian Pasang Surut}

Menurut Pariwono

(2009), fenomena pasang surut diartikan sebagai naik turunnya muka laut secara berkala akibat adanya gaya tarik benda-benda angkasa terutama matahari dan bulan terhadap massa air di bumi. Sedangkan menurut Dronkers (1964), pasang surut laut merupakan suatu fenomena pergerakan naik turunnya permukaan air laut secara berkala yang diakibatkan oleh kombinasi gaya gravitasi dan gaya tarik menarik dari benda-benda astronomi terutama oleh matahari, bumi dan bulan. Pengaruh benda angkasa lainnya dapat diabaikan karena jaraknya lebih jauh atau ukurannya lebih kecil.

Pasang surut yang terjadi di bumi ada tiga jenis yaitu: pasang surut atmosfer (atmospheric tide), pasang surut laut (oceanic tide) dan pasang surut bumi padat (tide of the solid earth). Pasang surut laut merupakan hasil dari gaya tarik gravitasi dan efek sentrifugal. Efek sentrifugal adalah dorongan ke arah luar

pusat rotasi. Gravitasi bervariasi secara langsung dengan massa tetapi berbanding terbalik terhadap jarak. Meskipun ukuran bulan lebih kecil dari matahari, gaya tarik gravitasi bulan dua kali lebih besar daripada gaya tarik matahari dalam membangkitkan pasang surut laut karena jarak bulan lebih dekat daripada jarak matahari ke bumi. Gaya tarik gravitasi menarik air laut ke arah bulan dan matahari dan menghasilkan dua tonjolan (bulge) pasang surut gravitasi di laut. Lintang dari tonjolan pasang surut ditentukan oleh deklinasi, sudut antara sumbu rotasi bumi dan bidang orbital bulan dan matahari.

\section{Waktu dan Tempat Penelitian}

Peneliti melaksanakan penelitian di MV. OMS Bromo yang merupakan salah satu kapal bulk carrier milik Orchard Maritime Services yang beralamatkan di Menara Prima floor 22G Jln. Dr. Lingkar Mega Kuningan blok 6.2 Jakarta-Selatan 12950.

Peneliti melakukan praktek laut sebagai deck cadet di kapal MV. OMS Bromo. Waktu penelitian dilaksanakan selama 12 bulan dari Juli 2015 sampai dengan Agustus 2016. MV. OMS Bromo merupakan salah satu kapal bluk carrier dengan rute tetap yaitu dari Tanah Grogot, Kalimantan Timur ke Paiton, Probolinggo, Jawa Timur. Semua awak kapal MV. OMS Bromo berkebangsaan Indonesia

Jumlah awak kapal MV. OMS Bromo terdiri dari 17 awak kapal termasuk Nakhoda. Awak kapal tersebut terdiri dari 1 orang Master, 3 orang Officers, 1 orang Chief Engineer, 2 orang Engineers, 1 orang Cook, 2 orang $A / B, 1$ orang Botswain, 1 orang Electrician, 3 orang oilers, 1 orang Deck Cadet dan 1 orang Engine Cadet.

MV. OMS Bromo adalah kapal jenis open deck cargo atau bulk carrier dengan DWT 13,000 tonnes pada summer draft $5.714 \mathrm{~m}$. Kapal ini dimulai pembangunannya pada tanggal 28 Desember 2012 di Shanghai Zhenhua Heavy Industries Shipyard, Cina dan peluncuran kapal pada tanggal 10 April 2013. Kapal OMS Bromo adalah kapal pertama sbelum OMS Ijen dan yang terakhir OMS Semeru. Ketiga kapal ini 
dibuat masing-masing berselang waktu empat bulan.

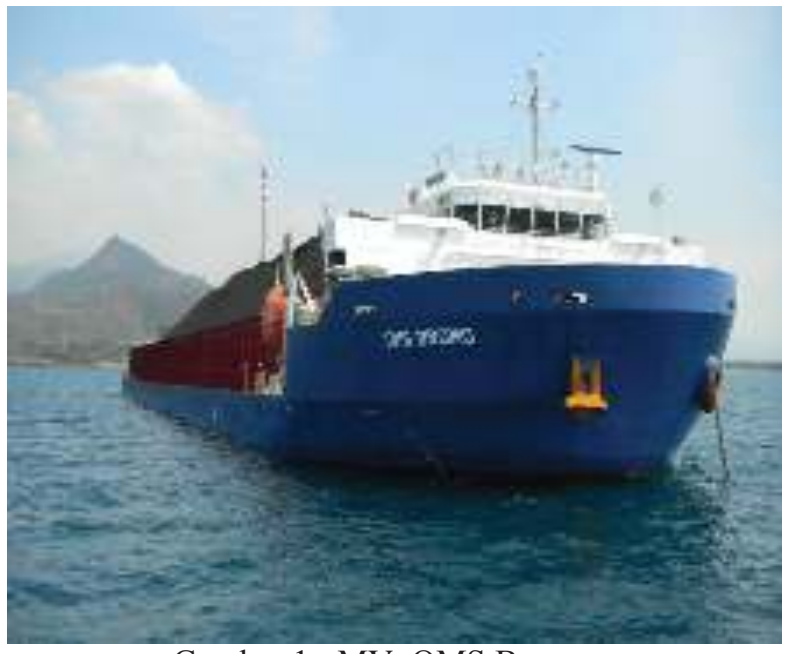

Gambar 1 : MV. OMS Bromo

Adapun data-data kapal tempat peneliti melaksanakan praktek laut sebagai deck cadet adalah sebagai berikut:

$\begin{array}{ll}\text { Ship's Name } & \text { : OMS Bromo } \\ \text { Call sign } & \text { : JZHW } \\ \text { IMO no. } & : 9682681 \\ \text { MMSI no. } & : 525018103 \\ \text { Class } & : \text { KR } \\ \text { Nationality } & : \text { INDONESIA } \\ \text { Port of Registry } & : \text { JAKARTA } \\ \text { Air draught } & : 25.174 \mathrm{~m} \\ \text { L O A } & : 127.73 \mathrm{~m} \\ \text { L B P } & : 121.16 \mathrm{~m} \\ \text { Breadth (MLD) } & : 26 \mathrm{~m} \\ \text { Depth (MLD) } & : 8 \mathrm{~m} \\ \text { Design draft (MLD) } & : 5.5 \mathrm{~m} \\ \text { Summer draft (EXT) } & : 5.714 \mathrm{~m} \\ \text { Displacement } & : 16,143.40 \text { tonnes } \\ \text { Deadweight } & : 13,000 \text { tonnes } \\ \text { Gross tonnage } & : 9,957\end{array}$

\section{METODE PENELITIAN}

Suatu penelitian merupakan suatu karya ilmiah yang mempunyai metode dalam mengerjakannya sehingga diharapkan susunan kandungan dan isinya dapat berbobot. Dalam penulisan penelitian ini metode penelitian yang digunakan adalah metode penelitian kualitatif. Menurut Sugiyono (2013:14), metode penelitian kualitatif adalah metode penelitian yang berlandaskan pada filsafat positivisme, digunakan untuk meneliti pada kondisi objek yang alamiah, dimana peneliti adalah instrumen kunci, pengambilan sampel data dilakukan secara purposive dan snowbaal, teknik pengumpulan dengan trianggulasi, analisa data bersifat induktif/kualitatif, dan hasil penelitian kulalitatif lebih menekan makna daripada generalisasi.

Menurut Afifuddin (2012:57-58), metode penelitian kualitatif ini sering disebut metode penelitian naturalistik karena penelitiannya dilakukan pada kondisi yang alamiah (natural setting) disebut juga sebagai metode etnografi karena pada awalnya, metode ini lebih banyak digunakan untuk penelitian bidang antropologi budaya, dan disebut sebagai metode kualitatif karena data yang terkumpul dan analisisnya lebih bersifat kualitatif. Maka dari itu dalam pembahasan penelitian ini, peneliti akan memaparkan semua hasil yang didapat mengenai objek yang diteliti di atas kapal MV. OMS Bromo.

\section{A. Sumber Data}

Dalam penelitian tentu dibutuhkan suatu sumber yang menjadi acuan yang disebut data. Menurut Moleong (2006: 157), data adalah teknik atau cara-cara yang dapat digunakan untuk mengumpulkan data, pengumpulan data dimaksudkan untuk memperoleh bahan-bahan yang relevan, akurat, dan nyata. Sementara menurut Purwanto dan Sulistyastuti (2007: 19), data adalah bahan mentah yang perlu diolah sehingga menghasilkan informasi atau keterangan yang menunjukkan fakta.

Berdasarkan definisi di atas dapat disimpulkan bahwa dalam menyusun penelitian ini akan dikemukakan beberapa metode atau teknik pengumpulan data, di mana data yang dikumpulkan peneliti adalah pengamatan secara langsung selama berolah gerak di alur pelayaran sempit perairan Tanah Grogot MV. OMS Bromo pada pemuatan batu bara di pelabuhan muat Kalimantan Timur. Berdasarkan cara 
memperolehnya, data terbagi menjadi dua jenis:

\section{Data primer}

Menurut Purwanto dan Sulistyastuti (2007: 20), data primer adalah data yang dikumpulkan secara langsung dari lapangan penelitian, yaitu hasil observasi langsung terhadap kegiatan operasional kapal MV. OMS Bromo pada saat perhitungan stability criteria selama memuat muatan general cargo dan curah.

Berdasarkan definisi di atas dapat disimpulkan bahwa data primer adalah data yang berasal dari sumber asli atau pertama. Data ini tidak tersedia dalam bentuk terkompilasi ataupun data-data. Data ini harus dicari melaui narasumber atau di dalam istilah teknisnya responden, yaitu orang yang dijadikan sebagai sarana untuk mendapatkan informasi ataupun data, dalam hal ini adalah Nakhoda, Mualim I dan Mualim jaga yang lain.

\section{Data sekunder}

Menurut Purwanto dan Sulistyastuti (2007: 20), data sekunder adalah data yang diperoleh melalui penelitian terdahulu yang dilakukan oleh pihak lain. Data sekunder yang diperoleh peneliti melalui buku-buku referensi, buku-buku pelajaran, IMO Publication dan buku lain yang berhubungan dengan materi yang dibahas dalam penelitian ini.

Berdasarkan definisi di atas dapat disimpulkan bahwa data sekunder adalah data yang diperoleh dari sumber tidak langsung yang biasanya berupa data dokumentasi dan arsip-arsip resmi. Data sekunder dalam penelitian ini berupa IMO Resolution, buku-buku Tide table, Manual book of RADAR, Olah gerak kapal, Colregs, Ship routeing.

\section{B. Metode Pengumpulan Data}

Metode pengumpulan data merupakan suatu bagian yang penting dalam penelitian, karena tujuan utama dari penelitian adalah mendapatkan data. Menurut Sugiyono (2008: 193), metode pengumpulan data adalah teknik atau cara-cara yang dapat digunakan oleh peneliti untuk mengumpulkan data. Pengumpulan data dapat dilakukan dalam berbagai setting, berbagai sumber dan cara. Masing-masing data memiliki kelebihan dan kekurangan sendiri-sendiri. Oleh karena itu lebih baik dipergunakan suatu pengumpulan data lebih dari satu. Sehingga semua dapat saling melengkapi satu sama lain.

Dalam penelitian ini digunakan beberapa teknik pengumpulan data antara lain:

\section{Riset lapangan}

Teknik pengumpulan data dilakukan dengan cara observasi secara langsung pada objek penelitian yaitu upaya bernavigasi yang aman saat berlayar di alur pelayaran sempit perairan Tanah Grogot, Kalimantan Timur di MV. OMS Bromo yang dilewati sebanyak empat kali dalam sebulan dan mengamati situasi alur pelayaran yang ramai.

2. Metode wawancara (Interview)

Metode ini digunakan untuk mendapatkan data dan keterangan dengan cara melakukan wawancara langsung kepada responden atau pihakpihak yang terkait dengan objek penelitian. Disamping itu juga wawancara langsung kepada orangorang yang lebih berkompeten dalam hal tersebut.

3. Dokumentasi

Dokumen merupakan catatan peristiwa yang sudah berlalu. Dokumen bisa berbentuk tulisan, gambar atau karya-karya monumental dari seseorang. Menurut Sugiyono (2009: 329), Teknik dokumentasi adalah cara mengumpulkan peristiwa yang sudah berlalu. Dokumen bisa berupa tulisan, gambar, atau karya-karya monumental dari seseorang. Hal ini digunakan untuk mendukung penelitian agar memperkuat bukti-bukti yang ada. Untuk membuat pembaca bisa memahaminya, 
dokumentasi yang digunakan harus berhubungan dengan objek yang dibahas. Untuk itu peneliti menggunakan foto-foto yang berhubungan dengan proses berolah gerak MV. OMS Bromo pada alur pelayaran sempit Tanah Grogot, Kalimantan Timur.

\section{Teknik Analisis Data}

Metode yang digunakan untuk menganalisi data yang ada dalam penelitian ini adalah menggunakan metode kualitatif dimana dalam penelitian dibutuhkan suatu analisis data. Menurut Purwanto dan Sulistyastuti (2007: 109), Analisis data adalah penyederhanaaan data ke dalam bentuk yang lebih mudah dipahami untuk diinterpretasikan. Dalam penelitian ini peneliti menggunakan metode analisis data, dengan cara menganalisis data-data yang diperoleh dari penelitian. Selanjutnya peneliti membuat penyajian data. Penyajian data ini merupakan penjabaran dari datadata yang telah diperoleh dari hasil penelitian sebelumnya yang telah disusun dengan urut sehingga diperoleh penyajian data yang mudah dipahami dan dimengerti oleh pembaca.

Dalam penulisan penelitian ini, peneliti menggunakan 3 (tiga) metode analisis data antara lain:

\section{Reduksi data}

Dalam sebuah data tentu terdiri dari beberapa bagian yang luas, sehingga diperlukan reduksi data agar penelitian menjadi terfokus. Menurut Sugiyono (2008: 338), mereduksi data adalah merangkum, memilih hal-hal yang pokok, memfokuskan pada hal-hal yang penting, dicari tema dan polanya dan membuang yang tidak perlu. Dengan demikian data yang telah direduksi akan memberikan gambaran yang lebih jelas, dan mempermudah peneliti untuk melakukan pengumpulan data selanjutnya, dan mencarinya bila diperlukan.

Berdasarkan definisi di atas dapat disimpulkan bahwa reduksi dapat didefinisikan sebagai proses pemilihan, pemusatan perhatian pada penyederhanaan, pengabstraksian dan transformasi data kasar yang muncul dari catatan-catatan tertulis di lapangan.

2. Penyajian data

Setelah data direduksi dan dipilah maka data akan disajikan secara sistematis. Menurut Sugiyono (2008: 141), penyajian data ini dapat dilakukan dalam bentuk tabel, grafik, pie chart, pintogram dan sejenisnya. Melalui penyajian data tersebut, maka data diorganisasikan dan tersusun pola hubungan sehingga akan lebih mudah dipahami.

Berdasarkan definisi di atas, dapat disimpulkan bahwa penyajian data merupakan sekumpulan informasi yang telah disusun secara terpadu dan mudah dipahami yang memberikan kemungkinan adanya penarikan kesimpulan dan pengambilan tindakan.

3. Menarik kesimpulan

Menarik kesimpulan merupakan kemampuan seorang peneliti dalam menyimpulkan temuan data yang diperoleh selama proses penelitian berlangsung.

\section{HASIL PENELITIAN DAN DISKUSI}

\section{A. Gambaran Umum}

1. Peran Mualim jaga saat bernavigasi di alur sempit perairan Tanah Grogot adalah:

a. Mengecek pasang surut perairan

Perairan sempit sangat dipengaruhi oleh pasang surut dan arus yang kuat sehingga ketika kapal akan memasuki pelayaran sempit, Nakhoda dan perwira jaga harus mengecek terlebih dahulu tabel pasang surut di perairan tersebut, guna menghindari kandasnya kapal saat memasuki alur tersebut.

Adapun cara untuk membaca tabel pasang surut yaitu:

1) Mengetahui posisi kapal

2) Waktu kapal 
3) Mengetahui koreksi bulanan

4) Keterangan tentang perairan tersebut

5) Menyesuaikan tanggal dan jam pada saat kapal berada

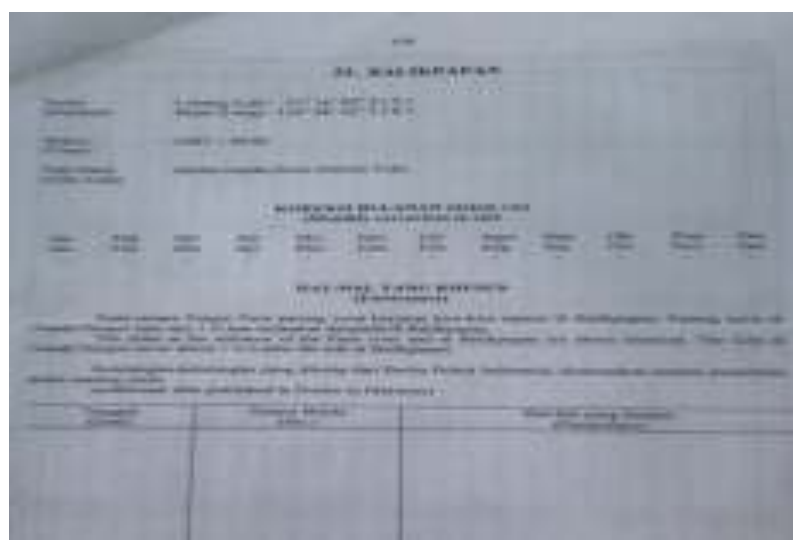

Gambar 2 : Tabel pasang surut

Pada saat kapal memasuki perairan sempit Tanah Grogot tanggal 6 Agustus 2015 pukul 20.00 WITA, pasang surut perairan Tanah Grogot terhitung $13 / 4 \quad$ jam lebih lambat daripada di Balikpapan, sehingga memakai pasang surut pada pukul 18.00 WITA.

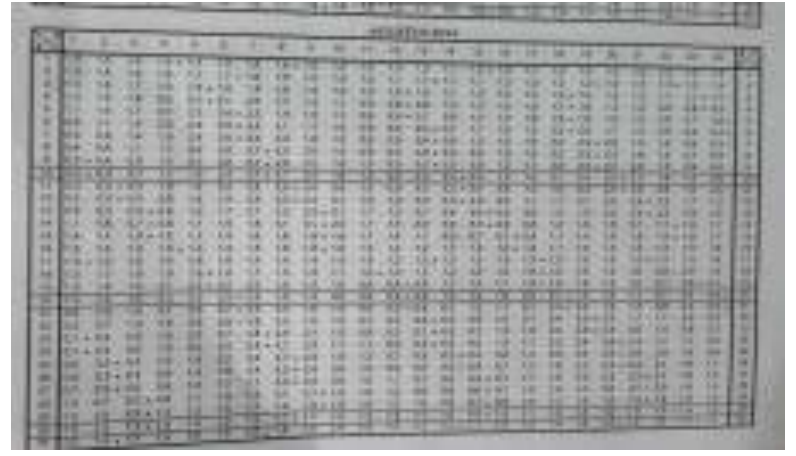

Gambar 3: Tabel pasang surut

b. Komunikasi antar kapal-kapal

Alur pelayaran Tanah Grogot merupakan alur yang ramai dan banyak kapal-kapal melintas keluar masuk alur serta banyaknya kapal nelayan menangkap ikan disekitar perairan tersebut, Nakhoda perlu berkomunikasi antar kapal-kapal dengan menggunakan semua alat komunikasi yang ada dengan tujuan agar tidak terjadi bahaya tubrukan kapal yang dapat merugikan banyak pihak

Alat komunikasi sangat penting di atas kapal yang bertujuan untuk berkomunikasi antara kapal satu dengan yang lainnya, seperti yang dijelaskan pasa SOLAS (Safety Of Life At Sea) Bagian 4 Aturan 6 tentang Instalasi radio yang dapat dilihat pada lampiran 2. Pada perairan Tanah Grogot yang merupakan alur pelayaran sempit dan dilalui oleh berbagai macam kapal maka komunikasi antar kapal sangat penting. Tujuan dari sistem komunikasi ini adalah:

1) Meningkatkan keselamatan navigasi,

2) Melindungi lingkungan laut,

3) Mempermudah pergerakan kapal.

Tidak adanya kapal ikan yang memiliki alat komunikasi seperti radio VHF, ini menjadi salh satu kendala dalam berkomunikasi saat berolah gerak di alur pelayaran sempit. Pada aturan 34 yang tentang isyarat-isyarat olah gerak dan isyarat-isyarat peringatan mengatur tentang isyaratisyarat olah gerak dan isyarat peringatan. Adapun isi dari aturan tersebut yaitu :

1) Bilamana kapal-kapal dalam keadaan saling melihat, kapal tenaga sedang berlayar, bilamana berolah gerak sebagaimana diperbolehkan atau diwajibkan oleh aturan-aturan ini, harus menunjukkan olah geraknya dengan isyarat- isyarat pada suling sebagai berikut :

Satu tiup pendek berarti "saya sedang merubah haluan saya ke kanan";

Dua tiup pendek berarti "saya sedang merubah haluan saya ke kiri"; 
Tiga tiup pendek berarti "saya sedang menggerakkan mesin mundur".

2) Setiap kapal boleh menambah isyarat suling yang diatur dalam paragraf (a) aturan ini dengan isyarat-isyarat cahaya, berulangulang seperlunya, sementara olah gerak itu dilaksanakan :

a) Syarat-isyarat cahaya ini mempunyai pengertian berikut:

Satu cerlang berarti "saya sedang merubah haluan saya ke kanan";

Dua cerlang berarti "saya sedang merubah haluan saya ke kiri;

Tiga cerlang berarti "saya sedang menggerakkan mesin mundur".

b) Lamanya waktu setiap cerlang kira-kira satu detik, selang waktu antara cerlangcerlang itu kira-kira satu detik dan selang waktu antara isyarat-isyarat yang berurutan tidak kurang dari sepuluh detik.

c) Penerangan yang digunakan untuk isyarat ini, jika dipasang harus berupa penerangan putih keliling, dapat kelihatan pada jarak paling sedikit 5 mil dan memenuhi ketentuan dari ketentuan tambahan I dari peraturan ini.

3) Bilamana saling melihat dalam perairan sempit atau alur pelayaran :

a) Kapal yang bermaksud menyusul kapal lain, dalam memenuhi aturan 9 (e).(i), harus menunjukkan maksudnya dengan isyaratisyarat berikut dengan suling ;

Dua tiup panjang diikuti satu tiup pendek, berarti "saya bermaksud menyusul melewati lambung kanan anda";

Dua tiup panjang diikuti dua tiup pendek berarti "saya bermaksud menyusul melewati lambung kiri anda".

b) Kapal yang akan disusul bilamana bertindak sesuai dengan aturan 9 (e).(i), harus menunjukkan persetujuannya dengan isyarat berikut ini dengan suling;

Satu tiup panjang, satu tiup pendek, satu tiup panjang, satu tiup pendek, menurut keperluan itu. Jika tidak setuju 5 tiupan pendek dan cepat.

4) Bilamana kapal saling melihat sedang mendekati satu sama lain, dan oleh alasan apapun, salah satu kapal tidak mengerti maksud atau tindakan kapal lain, atau ragu-ragu apakah tindakan yang dilaksanakan kapal lain cukup untuk menghindari tubrukan, kapal yang ragu-ragu itu harus menunjukkan keraguraguannya dengan memberikan isyarat sekurang-kurangnya lima tiup pendek dan cepat dengan suling. Isyarat demikian boleh ditambah dengan isyarat cahaya yang terdiri dari sekurangkurangnya 5 cerlang pendek dan cepat.

5) Kapal yang sedang mendekati tikungan atau daerah alur pelayaran atau air pelayaran sempit, di mana kapal-kapal lain mungkin terhalang oleh rintangan, harus membunyikan satu tiup panjang. Isyarat demikian harus dijawab dengan tiup panjang oleh setiap kapal yang sedang mendekati yang mungkin berada dalam jarak pendengaran di sekitar tikungan atau di belakang rintangan. 
c. Perairan Tanah Grogot merupakan perairan yang sempit dan ramai sehingga setiap kapal harus mengatur kecepatannya untuk mencegah terjadinya tubrukan antar kapal. Nakhoda harus menginformasikan terlebih dahulu pada kamar mesin untuk persiapan olah gerak kapal agar dapat mengatur kecepatan aman kapal untuk berolah gerak dan salah satu Masinis akan standby di anjungan untuk berolah gerak.

Aturan yang menyangkut tentang kecepatan aman yaitu aturan 6 P2TL yang menjelaskan tentang kecepatan aman kapal. Isi dari aturan 6 P2TL yaitu :

Setiap kapal harus selalu bergerak dengan kecepatan aman, sehingga dapat mengambil tindakan yang layak dan efektip untuk menghindari tubrukan serta dapat dapat diberhentikan dalam jarak sesuai dengan kondisi dan keadaan yang ada. Faktor-faktor dalam menentukan kecepatan aman yang harus diperhitungkan antara lain :

1) Oleh semua kapal :

a) Keadaan penglihatan;

b) Keadaan lalu lintas, termasuk pemusatan kapal-kapal ikan atau kapal-kapal lain;

c) Kemampuan olah gerak, khususnya yang berhubungan dengan jarak henti dan kemampuan berputar dalam kondisi yang ada;

d) Pada malam hari adanya cahaya latar belakang misalnya dari penerangan di darat atau dari pantulan penerangan sendiri;

e) Keadaan angin, laut dan arus, dan bahaya navigasi yang ada di sekitar;

f) Sarat, sehubungan dengan kedalaman air yang ada.
2) Sebagai tambahan, bagi kapalkapal yang dilengkapi dengan Radar yang bekerja dengan baik.

a) Ciri-ciri, efisiensi dan keterbatasan pesawat Radar;

b) Setiap pembatasan yang disebabkan oleh skala yang dipergunakan;

c) Pengaruh keadaan laut, cuaca dan sumber interferensi lain pada deteksi Radar;

d) Kemungkinan bahwa kapalkapal kecil, es dan bendabenda terapung lainnya tidak dapat dideteksi oleh radar pada jarak yang cukup;

e) Jumlah, posisi dan pergerakan kapal-kapal yang dideteksi oleh radar;

f) Berbagai penilaian penglihatan yang lebih pasti yang mungkin didapat bila radar digunakan untuk menetukan jarak kapal-kapal atau benda-benda lain disekitarnya.

Perairan sempit Tanah Grogot merupakan perairan sungai, sehingga ada beberapa hal yang harus diperhatikan yaitu :

1) Alur sebelah mana yang terdalam.

2) Dimana terdapat ambang atau tempat yang dangkal.

3) Disisi atau sebelah manakah terdapat arus yang paling kuat.

4) Dan disisi mana yang arusnya paling lemah.

2. Alur pelayaran sempit perairan Tanah Grogot

Alur pelayaran Tanah Grogot di kategorikan sebagai alur pelayaran sempit sehingga keluar masuk kapal pada alur pelayaran sempit tersebut sangat berpengaruh pada peran Mualim jaga saat bernavigasi. Bentangan melintang perairan yang tidak lebar memerlukan tingkat kehati-hatian yang tinggi dalam bernavigasi. Apabila salah memilih 
alur dapat berisiko kandas. Terutama di daerah pelabuhan Pondong karena pada daerah tersebut memiliki kedalaman air yang dangkal, banyak kapal-kapal yang sedang berlabuh dan harus secara rutin mengecek echo sounder. Saat memasuki alur Adang Bay menuju perairan Tanah Grogot ataupun sebaliknya merupakan alur pelayaran sempit yang memiliki pasang surut yang sangat berpengaruh terhadap navigasi kapal. Sebelum kapal bernavigasi melewati alur pelayaran sempit harus mengetahui pasang surut pada daerah tersebut, guna menghindari kandasnya kapal saat berlayar di alur perairan sempit. Alur pelayaran sempit Tanah Grogot memiliki panjang kurang lebih jarak $30 \mathrm{Nm}$ dengan waktu tempuh 4 jam dan memiliki kedalaman 7 meter pada saat pasang tertinggi dan kedalaman 4 meter saat pasang terendah. Dari Adang Bay sampai ke Tanah Grogot merupakan daerah rawan kandas. Di alur pelayaran tersebut terdapat 6 buah bouy dan satu suar penuntun untuk memandu kapal-kapal yang keluar masuk daerah tersebut agar terhindar dari kemungkinan kapal kandas dengan dibantu menggunakan alat bantu navigasi elektronik seperi Radar dan Echosunder.

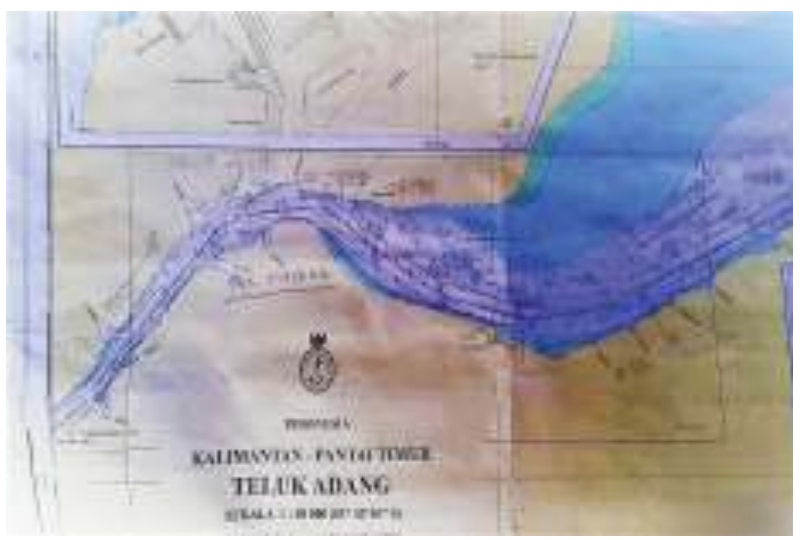

Gambar 4 : Alur perairan sempit Tanah Grogot di peta

\section{B. Hasil Penelitian}

1. Cara bernavigasi yang aman di alur pelayaran sempit Tanah Grogot, Kalimantan Timur.

Bernavigasi aman MV. OMS Bromo saat memasuki alur dari Adang Bay menuju Tanah Grogot, Kalimantan Timur meliputi 2 hal, yaitu :

a. Menentukan posisi

Berdasarkan hasil pengamatan yang dilakukan di atas kapal di alur Adang Bay menuju perairan Tanah Grogot, Kalimantan Timur ataupun sebaliknya merupakan alur pelayaran sempit yang mana untuk menentukan posisi kapal harus mengambil baringan-baringan benda darat, tanjung, gunung pelampung, atau baringan benda angkasa agar kapal selalu on track maka baringan yang di ambil harus benar (sejati), untuk itu kesalahan pedoman harus selalu diketahui. Selain itu juga penentuan posisi kapal harus sedapat mungkin menggunakan lebih dari satu benda baringan agar kesalahan pengambilan sekecil mungkin sehingga berpengaruh terhadap navigasi kapal MV. OMS Bromo. Saat kapal memasuki alur pelayaran sempit harus diketahui posisi kapal dengan tepat secara berkelanjutan agar kapal dapat terhindar dari bahaya kandas.

\section{b. Parallel index}

Berdasarkan hasil observasi yang dilakukan, metode yang berguna untuk memantau lintasan atau track kapal agar kapal selalu on track dengan menggunakan Parallel index. Dengan cara ini Mualim jaga dapat menentukan posisi yang diperolehnya dengan alat bantu navigasi lainnya pada saat kondisi lalu-lintas yang padat $d$ alur pelayaran sempit sempit dari Adang Bay menuju Tanah Grogot. Untuk bernavigasi yang aman, 
kapal harus menggunakan metode Parallel index dikarenakan banyaknya jumlah kapal yang melintas atau melewati di alur pelayaran sempit dari Adang Bay menuju Tanah Grogot atau sebaliknya.

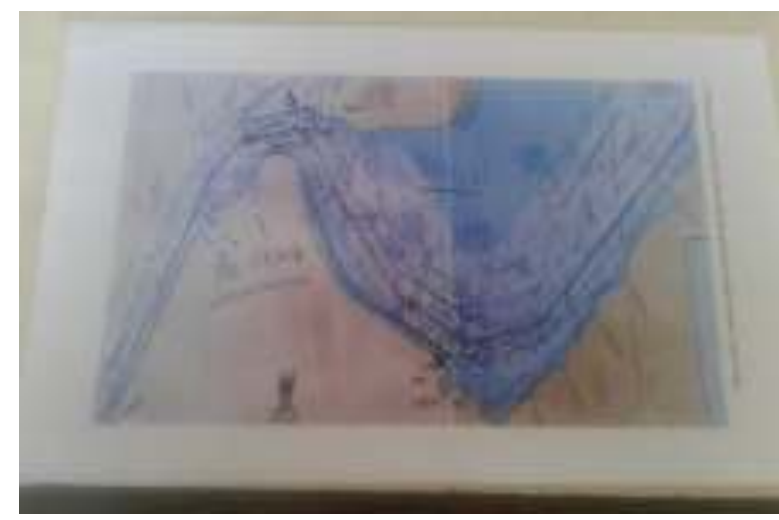

Gambar 5: Parallel index di peta saat keluar alur sempit

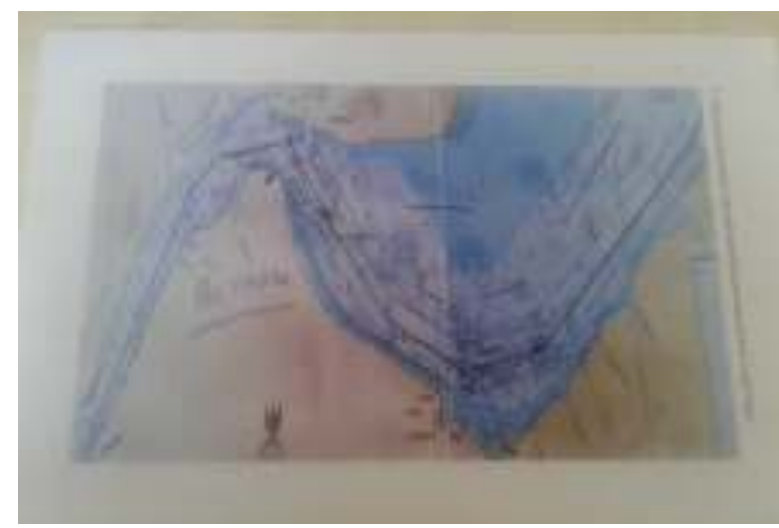

Gambar 6 : Parallel index di peta saat masuk alur sempit

2. Peran Mualim jaga untuk bernavigasi yang aman saat melakukan olah gerak di alur pelayaran sempit Tanah Grogot Nakhoda dan Mualim jaga berperan penting dalam bernavigasi aman MV. OMS Bromo saat melakukan sandar di alur sempit perairan Tanah Grogotr. Adapun Nakhoda tidak sendiri dalam melaksakan tugasnya, Nakhoda dibantu oleh Mualim jaga dan Juru Mudi saat memasuki atau keluar di alur sempit Tanah Grogot .

Berikut peran Mualim jaga saat bernavigasi aman kapal di perairan Tanah Grogot meliputi 2 hal, yaitu : a. Panduan bernavigasi untuk perwira jaga

Berdasarkan hasil wawancara yang dilakukan pada saat kapal berolah gerak Mualim jaga di atas anjungan memiliki tugas masing-masing yaitu untuk pengecekan posisi kapal dan pengamatan keliling. Untuk bernavigasi yang aman, Mualim jaga pada saat berada di alur pelayaran sempit Tanah Grogot, Kalimantan Timur bertujuan agar perwira yang berada di anjungan bertugas semaksimal mungkin untuk membantu atau meringankan tugas Nakhoda saat melewati alur pelayaran sempit Tanah Grogot mengingat tidak adanya layanan jasa Pandu untuk kapal yang panjangnya kurang dari $200 \mathrm{~m}$, sehingga Nakhoda mengambil alih penuh komando ketika melakukan olah gerak di alur pelayaran sempit Tanah Grogot.

b. Ships routeing

Berdasarkan hasil observasi yang dilakukan di atas kapal pada saat bernavigasi di alur pelayaran sempit Tanah Grogot, untuk meningkatkan keamanan navigasi kapal di daerah setempat, dimana kepadatan lalu lintas sangat padat dan banyaknya pergerakan kapal pada daerah pelayaran yang terbatas, serta dipengaruhi oleh rintangan navigasi/ batas kedalaman air dan kondisi keadaan cuaca harus menggunakan Ships routeing.

\section{KESIMPULAN}

Berdasarkan uraian dan pembahasan masalah dalam penelitian ini, maka penulis dapat menarik kesimpulan yang terjadi di MV. OMS Bromo saat proses bernavigasi yang aman di alur pelayaran sempit perairan Tanah Grogot. Kesimpulan yang didapat adalah sebagai berikut: 
1. Upaya bernavigasi yang aman di alur pelayaran sempit Tanah Grogot adalah :

a. Menentukan posisi kapal dengan mengambil baringan-baringan benda darat, tanjung, gunung pelampung, atau baringan benda angkasa guna mendapatkan posisi kapal yang akurat agar kapal terhindar dari risiko kandas.

b. Menggunakan Parallel index sebagai cara untuk memantau posisi kapal agar selalu on track dan untuk menjaga kapal agar selalu berada pada jarak yang aman dengan kapal lain demi keselamatan kapal dalam bernavigasi yang aman di alur pelayaran sempit perairan Tanah Grogot.

2. Peran Mualim jaga saat berolah gerak di alur pelayaran sempit perairan Tanah Grogot adalah sebagai berikut:

a. Perwira jaga berperan penting dalam membantu Nakhoda saat melakukan olah gerak di perairan sempit Tanah Grogot mengingat tidak adanya jasa Pandu untuk kapal MV. OMS Bromo karena panjang kapalnya kurang dari $200 \mathrm{~m}$.

b. Ships routeing digunakan dalam bernavigasi yang aman di perairan alur pelayaran sempit Tanah Grogot, kondisi lalu lintas yang padat pada alur pelayaran sempit mengharuskan Nakhoda untuk meningkatkan kewaspadaannya. Selain itu juga dipengaruhi oleh adanya bahaya navigasi serta batas kedalaman perairan.

Berdasarkan hasil penelitian yang telah di dapat, maka diberikan saran-saran yang dapat berguna dalam bernavigasi yang aman di alur pelayaran sempit perairan Tanah Grogot. Saran-saran yang dapat sampaikan adalah sebagai berikut:

1. Saat berlayar di alur pelayaran sempit perairan Tanah Grogot, Mualim jaga harus menentukan posisi kapal secara akurat dengan mengambil baringanbaringan benda darat, tanjung, gunung, pelampung, atau baringan benda angkasa dan menggunakan Parallel index untuk memantau posisi kapal agar selalu on track.

2. Mualim jaga saat berolah gerak agar menggunakan ships routeing untuk bernavigasi yang aman di alur pelayaran sempit dengan memperhatikan panduan yang diberikan oleh Nakhoda.

\section{DAFTAR PUSTAKA}

Arikunto, S. 2010. Prosedure Penelitian. Jakarta: AM

Dronkers, J.J. 1964. "Tidal Computations in Reivers and Coastal Waters". Amsterdam : North Holland Publishing Company

Kinzo, I. 2011. Pengemudian Kapal. Jakarta: Seisando Publishing

Kurnia, A. 2014. Daftar Pasang Surut Kepulauan Indonesia. Jakarta: Dinas Hidro-Oseanografi TNI AL

Supriyono, H. dan Sulistyo, A. 2014. "System navigasi elektronika". Yogyakarta: Budi Utama

Supriyono, H. Dan Subandrijo, D. 2016. "Colreg 1972 dan dinas jaga anjungan edisi 2". Yogyakarta: Deepublish

Subandrijo, D. 2011. Olah Gerak Dan Pengendalian Kapal. Semarang: Badan Penerbit Universitas Diponegoro

Sugiyono. 2011. Metode Penelitian Kuantitatif, Kualitatif dan $R \& B$. Bandung: Alfa Beta

Peraturan Menteri Perhubungan Nomor : PM 57 Tahun 2015 Tentang Pemanduan dan Penundaan kapal. Jakarta 